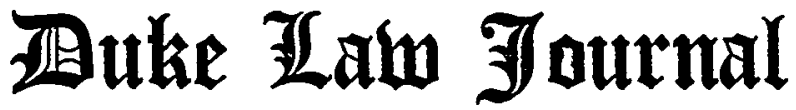

\begin{tabular}{lll}
\hline VOLUME 1960 & SPRING & NuMBeB 2 \\
\hline
\end{tabular}

\section{LEGAL AND ECONOMIC ASPECTS OF COMPETITION*}

\author{
Mark S. Massel
}

I

\section{Law and Economics in Antitrust}

\begin{abstract}
A NTITRUST, the central area in the field of competition, is probably unique among the government areas in which economic analysis can be applied. Since our antitrust laws are forms of business regulation, their application is focused on litigation. In contrast, government activity rarely provides occasions for litigation in such fields as stabilization, monetary and fiscal policy, international trade, and economic growth. ${ }^{1}$ Even when broad policy issues are considered in antitrust, the spotlight remains on litigation. The procedures applied in the pertinent administrative agencies, such as the Federal Trade Commission, are patterned after the courts. The emphasis is on litigation and the settlement of controversy, not on affirmative, nonlitigious government administration.

With this focus, it is only natural that lawyers should dominate the administration of our antitrust policies. Lawyers represent the govern-
\end{abstract}

* This article is largely based on a paper delivered during the Brookings Lectures 1958-59, and published under the title of Competition and Monopoly, in a volume entitled ECONOMICS AND THE POLICY MAKER, issued by the Brookings Institution in the fall of 1959 . We are indebted to the Brookings Institution for permission to republish the paper.

$\dagger$ B.S. r 930, M.A. 1933, J.D. I933, New York University. Senior Staff of the Brookings Institution; member of the New York and Illinois bars. Author, Business RESERVES FOR POST-WAR SURVIVAL, (1943). Contributor to professional publications.

${ }^{1}$ Public policy problems that lie outside the fields of government regulation of business do not contain significant legal elements. In those other areas, the economist advises the administrator and the policy-maker, who need not be a lawyer. In fact, there have been many occasions when economists have served as policy-makers. The application of economic analysis to public policy problems in these other areas of government activity are discussed in other lectures in the $1958-59$ Lectures of The Brookings Institution. See Colm, Economic Stabilization Policy; Jacoby, The Problem of Creeping Inflation; Roosa, Monetary and Credit Policy; and Hagen, Economics and Economic Development. 
ment and private plaintiffs, lawyers represent the defendants or respondents, judges adjudicate the controversies, and lawyers generally run the antitrust agencies and the pertinent congressional committees. Inevitably, lawyers play the central roles in the development and administration of our antitrust laws.

Therefore, a basic prerequisite for the adequate application of economic analysis in antitrust administration is to develop analytical tools that are useful for litigation procedures and can be effectively adapted to the skills of the lawyer.

Effective application of economic analysis in antitrust requires an appreciation of the differences in legal and economic methodology. The law provides rules that are based on a recognized structure of statutes and court decisions. True, there are many uncertainties in the law. However, they are all capable of resolution, though it may be temporary, by procedures operated within a clear framework.

Our legal system provides an effective mechanism for determining the winner and the loser in a controversy. Since the system is founded upon the technique of adversary proceedings, it requires that all parties accept the decision of the highest court which may be involved. Therefore, during the course of litigation, a lawyer is told whether he is right or wrong.

In contrast, the economist functions within a nebulous operational framework. Though he frequently must make predictions, there can be no clear determinations of his success or failure. ${ }^{2}$ Even if his colleagues or superiors-whether in government, business, or the universities-should agree with him, there is no mechanism for an unequivocal, overt determination of the correctness of his findings. In the final reckoning, the test of economic analyses is what takes place in the economy. However, even that test cannot be conclusive, because of the effects of forces and circumstances that are not covered by the analysis or that could not have been visualized at the time the analysis was made.

Another distinction between law and economics relates to the differences in the standardization of the technical terms used. ${ }^{3}$ In most fields, the law employs relatively well-defined terms that are accepted by all the participants. Meanings of most words of art are established through statutes and court decisions and can be proven through precedent. On the other hand, there is no organized procedure for fixing

\footnotetext{
2 HAYeK, Individualism and Economic ORder 73, 74 (1948).

s The same terms may have different meanings in law and in economics. See for example, differences in the concepts of monopoly in law and economics. Mason, Monopoly in Low and Economics, 47 YALE L.J. 34 (1937).
} 
the meaning of economic terms that will be accepted by all members of the profession. Since economic problems are harder to resolve, questions of terminology are especially difficult, and much attention is given to debates on the meaning of words.

Another set of problems in applying economic analysis in antitrust is technical in nature. Litigation, especially in the antitrust field, frequently calls for long drawn-out proceedings, with many technical involvements concerning the nature of the evidence that will be considered in the course of the case. Additionally, there are many subtle rules concerning the burden of proof, the weight of the evidence, and the theory of the case. Therefore, technical legal procedures, rather than straightforward economic analysis, determine what evidence will be heard and how it will be applied.

Cutting across these basic differences between the two disciplines are several factors that influence the relationships between the two professions. Lawyers, on the whole, are not accustomed to working with experts in other disciplines in planning or prosecuting a case. By and large, it seems fair to say that lawyers and judges prefer the freewheeling of their own understanding and of their own interpretations. ${ }^{4}$ Even though they employ experts from other fields as witnesses, they are not accustomed to consulting with these experts on equal terms. ${ }^{5}$

Lawyers also prefer working with concepts and techniques that they use regularly. For example, lawyers are much more comfortable when a case involves intent, conspiracy, or good faith than when it turns on such economic issues as a lessening of competition, or a tendency to create a monopoly. ${ }^{6}$ Given the lawyers' commanding position in this field, it seems only natural that they are not inclined to handle economic problems in a case if they have other alternatives. Therefore, whenever possible, antitrust litigation centers on issues of good faith and conspiracy rather than competition.

It would be an exaggeration to say that lawyers never seek help from the economists or that economic analysis has made no inroads in

'Riesman, Law and Sociology: Recruitment, Training and Colleagueship, 9 STAN. L. REV. 643,65 I (1957).

"Grether describes economists as "handmaidens of the lawyers" in the antitrust field. Grether, Economic Analysis in Antitrust Enforcement, 4 ANTITrust Bull. 55 (1959).

- In his study United States v. United Shoe Machinery Corporation: AN Economic ANALYSIS of AN ANTI-TRUST CASE 335 (1956), Carl Kaysen said: 'Indeed, it is no exaggeration to say that an overall view of the market and United's position in it hardly emerged from the Government's presentation of its case at all, so heavily was it pointed toward 'intent.' United likewise used most of its presentation for material of the same kind." See DirLam \& KaHN, Fair Competition 45-54 (1954). 
law practice. Antitrust lawyers, whether they stand in front of our judicial benches or sit behind them, have exhibited a growing awareness of the economic aspects of antitrust problems. ${ }^{7}$ However, because of the lawyers' predilection for issues of intent and good faith, it has not been easy for them to plunge into unknown, imprecise economic analysis when they can handle a case on a theory of good faith or conspiracy. ${ }^{8}$ Nor is it easy for them deliberately to forego filing charges of conspiracy in favor of proceedings that call for complex economic analysis.

On the other hand, economists have overlooked some strategic factors that influence the application of economic analysis in the antitrust field. On the whole, they have tended to neglect operative problems. They have not clearly recognized the need for economic tools that can be applied by the lawyers within a statutory and judicial framework. By and large, they have concentrated on methods of analysis that engage the interest of their fellow economists only. "They have overlooked, also, the need to develop analytical tools for forward action in order to help the lawyers to formulate court decrees that will inject competitive forces in a market. ${ }^{10}$ Instead, they have concentrated on interpretations of past developments, which are useful primarily in finding a violation of the antitrust laws. Lastly, their frequent failures to distinguish between issues of policy and issues of administration have limited the contributions of economic analysis in the broad field of competition.

The writer's thesis is that the tools of economic analysis will not be ultilized adequately in the field of competition and monopoly until lawyers and economists learn to co-ordinate their disciplines more effectively; that progress in this regard has been inadequate; and that we have scarcely started to realize the potential usefulness of economic analysis in either the development or administration of our competitive policies. In this article, the writer proposes to re-examine this thesis in the light of some of the operating problems involved in the formulation

\footnotetext{
${ }^{7}$ See, Lockhart \& Sacks, The Relevance of Economic Factors in Determining Whether Exclusive Arrangements Violate Section 3 of the Clayton Act, 65 HARv. L. REv. 913, $9 \times 9$ (1952). The article presents a plea for more economic analysis.

${ }^{8}$ Some economists feel that intent is the essential feature of an antitrust violation. See BURNs, A Study OF THE ANTitrust LaWs 57 (1958).

"See Alfred North Whitehead's general criticism of the "anti-rationalism of science." He feels that the "[science of political economy] fixes attention on a definite gronp of abstractions, neglects everything else. ..." WHITEHEAD, SCIENCE AND THE MODERN WORLD 288 (1929).

${ }^{10} \mathrm{~F}$. A. Hayek is critical of current economic discussions which center on the differences between perfect and imperfect competition. He feels there should be more attention given to the removal of suppressions of competition. See HAYEK, op. cit. supra note 2 , at 105 .
} 
of policy concerning competition and monopoly, and some aspects of the administration of the laws, including the negotiation and the trial of cases.

II

Policy Formulation

Policies affecting competition and monopoly are formulated through a number of channels. Some policies are developed directly through legislation-federal, state, and local. Most of them, however, are developed through judicial opinions, interpretations, and activities of administrative agencies, congressional investigations, and congressional pressures.

We have leaned heavily on our courts for the formulation of our antitrust law. We have adopted a "common law" system for developing the law, case by case, instead of spelling out detailed codes. The social theory behind the "common law" development is that the law will be hammered out gradually through adversary proceedings over a period of time.

Dependence upon court-developed law is clearly indicated by the generality of the language used in the antitrust laws. Thus, the key phrases in the Sherman Act, ${ }^{11}$ the first of these laws, are "restraint of trade" and "monopolize." The Clayton Act ${ }^{12}$ and the Robinson-Patman Act ${ }^{13}$ rely upon such clauses as "substantially to lessen competition, or to tend to create a monopoly." The Federal Trade Commission Act ${ }^{14}$ strikes at "unfair methods of competition."

In employing such general language, Congress intended that the specific content of the laws would be established through court or agency interpretations. The justification for such judicial development is that the law will be evolved slowly, since the courts, in moving case-by-case, can consider the effects of previous decisions. This evolutionary method should permit orderly consideration of the subject through the process of judging specific controversies which are presented by skilled lawyers who are close to the operating problems.

In the evolution of law through litigation, lawyers play central roles, whether they represent the government or private clients. On the government side, the selection of cases to prosecute is strategic. If a government agency decides not to prosecute a given practice, the courts are not afforded the opportunity to consider the question of law

\footnotetext{
${ }^{11} 26$ Stat. 209 (1890), 15 U.S.C. \$§ 1-7 (1952).

$12{ }_{3} 8$ Stat. 730 (1914), 15 U.S.C. $\$ \S 12-27$ (1952).

${ }_{13}{ }_{3} 8$ Stat. 730 (x914), I $_{5}$ U.S.C. $\$ \S \mathrm{x}_{3}, \mathrm{r}_{3} \mathrm{a}, \mathrm{x}_{3} \mathrm{~b}$ (1952).

${ }_{14}{ }_{3} 8$ Stat. 7 1 7 (1914), 15 U.S.C. $\$$ $_{41-58}$ (1952).
} 
which may be involved. On the private side, lawyers for plaintiffs in antitrust actions play a similar role, while lawyers for defendants play a vital part through their formulation and exposition of other theories of the law. The courts cannot determine, on their own, which theories to test or which cases to try.

Congressional investigations and pressures are of substantial import, even when they do not lead to new legislation. Administrative agencies must consider congressional reactions even when no statutory changes are in prospect. Congressional pressures and legislative inquiries can exert strong influences on the volume of activity of the agencies, on the vigor behind it, and on the direction it takes.

Over-all, these administrative, legislative, and judicial developments are influenced by the climate of public opinion. Through published analyses of industries and commentaries on judicial and administrative developments; economists and students of the law play increasingly important roles.

\section{A. Problem of Defining Objectives}

The formulation of competitive policies requires consideration of much more than our economic goals. Deep political and social aims also constitute important elements of our antitrust policy. ${ }^{15}$

While our most obvious concern is with economic efficiency and higher standards of living, the social and political implications of concentration of power have been major influences in the antitrust policy ${ }^{10}$ field. In fact, there has been substantial support of a militant antitrust policy from people who are interested primarily in broad political and social forces. ${ }^{17}$ They believe that an economy which is run entirely by

${ }^{25}$ Young, The Sherman Act and the Near Anti-trust Legislation, 23 J. Por. Econ. 214 (1915). Mr. Justice Black said, "The Sberman Act was designed to be a comprehensive charter of economic liberty. . . . It rests on the premise that the unrestrained interaction of competitive forces [will provide] an environment conducive to the preservation of our democratic, political and social institutions." Northern Pacific R.R. v. United States, 356 U.S. 1,4 (1957). Rostow, The New Sherman Act: A Positive Instrument of Progress, I4 U. CHI. L. REv. 567, 569-74 (1947); Gunton, The Economic and Social Aspect of Trusts, 3 Por. ScI. Q. $3^{85}$ (1888).

${ }^{26}$ DirLaM \& KaHN, op. cit. supra note 6, at $15-17$.

${ }^{17}$ Levi, The Antitrust Laws and Monopoly, I4 U. CHI. L. REv. 153, 155-56 (1947). Some elements of this striving for political and social results can be found in the history of development of both English and American attitudes toward monopoly. See Jones, Historical Development of the Law of Business Competition, 35 YALE L.J. 905 (1926),

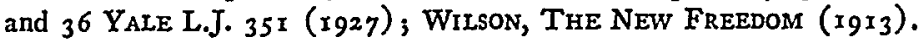

For a statement of this point of view in a discussion of Japanese antitrust law, see Ashino, Experimenting with Anti-Trust Law in Japan, 3 THE JAPANESE ANNUAL of INTERNATIONAL LAW 3 I (1959). 
large companies entails a number of antidemocratic consequences. They fear that the political and social influences of the middle-class in our society would be lost; that the leadership contributed by independent members of the liberal professions would be weakened; and that the loss of these strong influences would damage our democratic institutions. In general, they are not ready to rely on the good will of industrial giants and the newly-heralded "business statesmanship" as the major political forces in our society. ${ }^{18}$ They fear concentration of power in any form.

Another facet of these political and social objectives concerns the appropriate areas of governmental regulation. ${ }^{19}$ Many feel that a strong democratic society cannot endure under stringent government regulation. ${ }^{20}$ This does not imply that they favor a simple, uncomplicated laissez faire system. ${ }^{21}$ Rather, they are interested in utilizing the smallest practicable amount of government regulation. They. believe that, if competitive forces. were destroyed, pressure for government supervision of the dominating enterprises would be irresistible and we would lose our free enterprise system. ${ }^{22}$. Consequently, they feel that maintenance of active competition is vitally necessary if we are to avoid an economy dominated by government regulation. ${ }^{23}$

Recognition of these political and social objectives does not imply that the economic objectives play a minor role. Nor does it require that economic analysis should be reforinulated to encompass all three objectives. $^{24}$ Rather, an understanding of the three-way consideration of antitrust policy makes it even more important that the economists produce vigorous economic analyses of the policy problems.

It is assumed in many current discussions that there are many incompatibilities between economic efficiency and these political and social objectives. ${ }^{25}$ This assumption is premised on the belief that large com-

\footnotetext{
${ }^{18}$ Some do not want to rely on "business statesmanship" for economic reasons. "See Lewis, Economics by Admonition, 49 AM. Econ. Rev. 384 (I959).

${ }^{10}$ For an interesting discussion of these interrelations, see Hoover, THE ECONOMY, LIBERTY, AND THE STATE esp. ch. I3 (1959).

${ }^{20}$ HAYeK, The RQAd TO SERFDOM (1944).

${ }^{21} \mathrm{M}$. Rotondi feels that "it would be better to speak of equality in competition rather than freedom of competition." Rotondi, Unfair Competition in Europe, 7 AM. J. CoMP. L. 327,329 (1958).

${ }^{2}$ Simons, Some Reflections on Syndicalism, 52 J. PoL. EcoN. I, 5 (I944); SrockING \& Watkins, MONOPOLY AND FREE ENTERPRISE 548 (195I).

${ }^{23}$ Rostow, sitpra note 15 , at 573 .

"4 Viner, International Trade Theory and Its. Present Day Relevance, Economics AND PUBLIC POLICT 122 (1955).

${ }^{95}$ See Berle, The Twentieth Century Capitalist Revolution (I954); Burnham, The Managerial Revolution (194I); Lilienthal, Big Business: A New
} 
panies in concentrated industries produce goods and services with greater efficiency and lower costs than smaller, ${ }^{26}$ competitive enterprises and that they will generate more substantial innovations in products and services. ${ }^{27}$ Support of this premise does not always imply a willingness to discard the political and the social objectives in order to improve economic efficiency. However, it does imply that we need to weigh the relative importance of the various objectives for a clearer formulation of national policy.

Accordingly, one of the main challenges for economic analysis today is to provide for a clear, definitive picture of the influences of the competitive framework on efficiency, ${ }^{28}$ innovation, ${ }^{29}$ and the volume of production and employment. $^{30}$ For, if it were clear that the economic, political, and social objectives are compatible, we would avoid the fuzzy frustrations that beset the formulation of government policies in this field. Conversely, if it were shown that a diminution of competition would raise standards-of-living, we would have clearer-cut choices to consider. Then, we could weigh and balance among the objectives more effectively. We could decide whether we were willing to pay the price for these social and political objectives, or whether we preferred higher economic levels. ${ }^{31}$

Era (1952). See also, Galbraith, American Capitalism: The Concept of CounTERVAILING Power (1952).

${ }^{20}$ Seligman, Railway Tariffs and the Interstate Conmerce Law, 2 PoL. Sc1. Q. 369, 373 (1887). Clark, The Limits of Competition, 2 Por. Scr. Q. 45, 55 (1887); Gunton, supra note 15 , at 406 .

${ }_{27}$ Villard, Competition, Oligopoly, and Research, 66 J. Pol. EcoN. 483 (1958); Schumpeter, Capitalism, Socialism, and Democracr (r 942); Hadley, The Good and Evil of Industrial Combinations, 79 ATLANTIC MonTHLY 377 (1897). Contra, NutTER, THE ExTENT OF ENTERPRISE MONOPOLY IN THE UNITED STATES I 899-1939, 26 (I95I).

${ }^{28}$ For an affirmative conclusion, see MONOPOLIES AND RESTRICTIVE PRACTICES COMMISSION, REPORT ON THE SUPPLY AND EXPORT OF CERTAIN SEMI-MANUFACTURERS of COPPER ANd COPPER-BASEd Alloys para. 287 (1955); ANGLO-AMERICAN Council on Productivity, Industrial ENGINEERING (1954); ANglo-AMERICAN COUNCIL ON Productivity, Steel Founding (1949); ANglo-American Council on Productivity, Management Accounting (1950); Hutton, We Too Can Prosper (x953); Jewkes, Ordeal by Planning (1948).

${ }^{20}$ Edwards \& Townsend, Business ENTERprise 562, 564 (1958).

${ }^{30}$ For a current British argument in favor of competition on this score, see EDwards \& TownsEnd, op. cit. supra note 29. For a short discussion of the advantages and disadvantages of competition and monopoly, see WILCOx, COMPETITION AND MONOPOLY iN AMERICAN INDUSTRY (TNEC Monograph No. 2 I, I940).

${ }^{31}$ This question is implicit in Edward S. Mason's discussion of the writing of Schumpeter, Berle, Lilienthal, and Galbraith. See Mason, The Apologetics of "Managerialism," 3 I J. Bus, I (1958). 
If we were to adopt a consistent policy in favor of competition, we could forge clearer criteria for the application of the economic tools of analysis. We could then confine economic analysis of individual markets to the single criterion of whether they are competitive, without having to evaluate social performance on a broader basis. We could begin to develop a more logical pattern of government regulations. We could avoid the serious inconsistencies which generate both rules that encourage competition and regulations that stifle it. For example, in order to strengthen the over-all policy, we might apply a firm policy to promote competition even in those industries that might acquire greater efficiency through monopolistic practices, on the ground that such a consistent policy will produce better total results in our society. Conversely, if an in-between conclusion were reached, we would recognize the need for developing a method to determine those industries that do not require the same degree of competition as others. For example, we might conclude to tolerate anticompetitive trends in certain defense industries. ${ }^{32}$

We need a clearer understanding of the contribution of competition even in the implementation of our economic objectives. In recent years, we have progressed beyond the elemental objectives of higher efficiency in the allocation of resources to the more advanced problems of growth and stability. ${ }^{33}$ The contribution of competition to these more advanced objectives is still uncertain. ${ }^{34}$ There are some strong indications, fragmentary in nature, that competition contributes to growth. ${ }^{35}$ But, we need more definitive analyses. The problem of stability has many facets that are still to be uncovered. ${ }^{36}$ But, perhaps this area will not be ready for exploration until economic stability is itself defined. Does it mean stable employment, stable prices, steadily increasing employment, or some balanced combination of the three?

\section{B. Competitive Policies Broader Than Antitrust}

The policy issues concerning competition are not confined to the consideration of antitrust laws. They extend to many other phases of

\footnotetext{
${ }^{32}$ Judge Knox, among others, had to consider the national security problem in the Alcoa case. United States v. Aluminum Co. of America, 9 I F. Supp. 333, 347 (S.D.N.Y. I950).

${ }^{33}$ Mason, Price Policies and Full Employment, in FRIEDRICH \& MAsON (EDs.), Public Policy 25 (1940).

${ }^{34}$ For a discussion of the effects of competition on inflation and stability, see MEANs, Administrative INflation and Public. Policy (i 959 ). See also Jacoby, sulpra note 1 .

${ }^{36}$ See Simons, Economic Policy for a Free Societr (1948).

${ }^{36}$ See Reynolds, Wage Behavior and Inflation, in WAGES, PRICES, Profrrs, AND PRODUCTIVITY 109, 126 (1959).
} 
government activity which have strategic influences on the competitive framework. They apply to the many types of government regulation on the federal, state, and local levels. They also cover a number of nonregulatory activities.

Not all federal regulation is based on a clear competitive policy. For example, the protective tariffs, ${ }^{37}$ quotas, ${ }^{38}$ and "Buy American" regulations discourage foreign competition; ${ }^{30}$ tax laws encourage corporate acquisitions and discourage corporate spin-offs; ${ }^{40}$ regulation of communications and transportation prevents new business entrants ${ }^{41}$ and curtails rate competition. ${ }^{42}$ In addition, there is room for reasonable doubt about the competitive effects of some federal regulations which are supposedly dedicated to the protection of the small businessman. Thus, the Robinson-Patman Act ${ }^{43}$ and the federal encouragement of resale price maintenance have been criticized on this score. ${ }^{44}$

\footnotetext{
${ }^{37}$ For a suggestion that tariffs be reduced for the products of an industry that has violated the antitrust laws, see Probst, The Failitre of the Sherman Anti-trust Law, 75 U. PA. L. REv. 122 (1926). Several curious twists are found in tariff laws. Thus, the President can suspend a tariff concession if an international cartel affects the item in question. Trade Agreements Extension Act of 1955, 69 Stat. I62 (1955), 19 U.S.C. $\$ 1351$ (a) (4) (1952). The Treasury can double the tariff on an item which is controlled by exclusive dealiug arrangements. 60 Stat. 433 (1946), 15 U.S.C. § 93 (1952).

${ }^{38}$ Whittlesey, Import Quotas in the United States, 52 Q.J. EcoN. 37 (1937-38).

${ }^{30}$ For comment on the Buy American Act, see UNITEd STATES CoMmission ON Foreign EConomic Policy, Report to the President and the Congress 50 (1954).

${ }^{20}$ Butters \& Lintner, Tax and Non-Tax Motivations for Mergers, 6 J. Finance 361 (1951); see also Lintner \& Butters, Effects of Taxes on Concentration, in NATIONAL Bureat of Economic Research, Business Concentration and Price Policy 239 (1955). For a discussion of the specific problem of the tax effects of divestitures, see Hearings Before the House Committee of Ways and Means on H.R. 8x26, Taxation of Exchanges and Distributions Pursuant to Antitrust Decrees, 86th Cong., Ist Sess. (1959).

${ }^{22}$ See testimony of L. C. Halvorson, Hearings Before Senate Small Business Committee on ICC Administration of the Motor Carrier Act, 84th Cong., Ist Sess. I21 (1956).

"Note, Antitrust Immunity in the Communications Industry, 44 VA. L. REv. I 31 (I958); Staff of Subcomm. No. 5, House Comm. on the Judictary, 84th Cong., 2D Sess., Judicial Doctrine of Primary Jurispiction as Applied in ANTItrust SurTs (Comm. Print 1956). For a comment on the tendency of the ICC to raise trucking rates to the level of railroad rates, see U.S. BUREAU OF AGRICULTURAL ECONOMICs, Dep'T of Agriculture, Barriers to Internal Trade in Farm Products (1939). For a general discussion, see testimony of Marver H. Bernstein, Hearings Before Subcommittee No. 5 of the House Committee on the Judiciary on Monopoly Problems in Regulated Industries, 84th Cong., 2d Sess. 59 (1957).

${ }^{43}$ Stocking \& Watkins, op. cit. sitpra note 22 , at 533,538 . Council of Economic Advisers Third ANn. Rep. I5 (1948).

"See, e.g., Attorney General's National Committee to Study the ANTTTRust LAWs, REPort 49-55 (1955); Hermau, $A$ Note on Fair Trade, 65 YAle L.J. 23 (1955). Contra, Adams, Resale Price Maintenance: Fact and Fancy, 64 YALE L.J. 967 (I955); Brandeis, Cutthroat Prices: The Competition that Kills, Harper's Weekly, Nov. $15,19 \times 3$, p. 10.
} 
Two other problems on the federal level concern the competitive effects of the various antitrust exemptions allowed for agriculture ${ }^{45}$ and for labor unions. ${ }^{46}$ These are exceedingly bothersome problems because of their political overtones. Thus, labor unions have been able to charge that some critics of labor's broad exemptions are really anxious to undermine all union power. Objective economic analysis of these two sectors is badly needed if we are to achieve clear competitive policies.

State and local governments provide a host of regulations which limit competition. ${ }^{47}$ For example, various farm measures limit and promote price-setting by agricultural co-operatives. There are many substantial barriers to interstate commerce, ${ }^{48}$ such as dairy inspection requirements that limit the geographical areas of milk sheds, ${ }^{49}$ trucking regulations, and state labeling requirements for various products. Price competition is dulled by state regulations that permit fair trade ${ }^{50}$ as well as by some rules that practically compel control of resale prices. ${ }^{51}$ Provisions against selling below cost, ${ }^{52}$ or loss-leader limitations frequently conceal arrangements that boost prices substantially above the level of cut-throat pricing, although they are represented as regulations that will merely raise competition above this level. Many licensing rules limit entry into various businesses and curtail the competitive potential..$^{53}$ Such production controls, as those affecting petroleum, ${ }^{54}$ add to these forces. "

${ }^{45}$ See Stocking \& Watkins, op. cit. supra note 22, at 539; ATtORNEY General's National COMmitTeE to StUdy the Antitrust LAWs, Report 3 II-13 (1955); Benedict, Attempts to Restrict Competition in Agriculture, 44 AM. EcoN. REv. 93 (1954).

${ }^{40}$ Reynolds, supra note 36 , at 135; Machlup, The Political Economy of Monopoly ch. 9 (1952); AtTorney General's National COMmitTeE TO Study THE ANTITRUST LAWS, REPORT 304-06 (1955).

${ }^{47}$ Corwin D. Edwards argues that the policies of states and municipalities must be "inflnenced, so far as possible, toward patterns consistent with competition." EDWARDS, Maintaining Competition 291 (1949). See also $i d$. at 312 for federal efforts to influence state policies.

${ }^{48}$ U.S. Bureau of Agricultural Economics, Dep'T of A'Griculture, Barriers to Internal Trade in Farm Products (1939); National Conference on INTERstate Trade Barriers, Trade Barriers Among the States (1939).

${ }^{\circ 0}$ For the extensive range of milk regulation, see 3 Marketing LaWs Surver, STAte Milk and Dairy Legisiation (1941).

${ }^{\text {so }}$ See 2 Marketing Laws Survey, State Price Control Legislation (1940).

${ }^{21}$ See 4 Marketing Laws Survey, State Liquor Legislation (1941), esp. R.I., N.J., and Ky. See also, Marketing Laws Survey, Special Price Legislation (1942).

${ }^{82}$ See 2 Marketing Laws Survey, State Price Control Legislation (1940).

${ }^{8}$ Silverman, Bennett, \& Lechliter, Control by Licensing over Entry into the Market, 8 Law \& Contemp. Prob. 234, 25 I (194I); Marketing Laws Survey, State Occupational Legislation (1942).

54. The latest Interstate Compact to Conserve Oil and Gas may be found in Hearing 
Government purchasing is one of the important nonregulatory activities that can have a profound effect on competition. ${ }^{65}$ Because of the size and nature of federal, state; and local government purchases, ${ }^{60}$ for both military and civilian purposes, they cannot avoid influencing competition and monopoly. Thus, if the bulk of research and development contracts go to large companies, the long-run competitive effects may be quite significant. If contracts providing for government assistance in the construction of new facilities or for the purchase of existing government plants are confined to a select few, competition is affected. ${ }^{.57}$ On the other hand, some federal purchases are so large that they could be used to encourage new entrants in certain industries. If, in addition, means could be found to co-ordinate between federal, state, and local government purchases, it would be possible to exert a profound influence for competition.

\section{Broad Analysis of Competitive Conditions}

A realistic competitive policy requires a continuing diagnosis of competitive conditions in order to assist the Congress, the Executive, the .judiciary, and public opinion..$^{58}$

In recent years, there have been many conflicting reports about the state of competition. Some have reported a substantial weakening of

Before the Subcommittee on Communications and Power of the House Committee on Interstate and Foreign Commerce on Interstate Oil Compact, 86th Cong., Ist Sess. (1959).

${ }^{55}$ Some elements of government purchasing are tied up with regulatory and volurtary activities under the Defense Production Act of $1950, \S 708(\mathrm{e})$ of which, as amended, directs the Attorney General to make surveys to determine factors which may influence competition, monopoly, and concentration of economic power. 65 Stat. 139 (1950), 50 U.S.C. $\S 2058$ (e) (1952). He is directed to study voluntary industry agreements authorized by the Act. The Attorney General makes regular reports covering these studies, to the Congress and President. See, e.g., Attorney General, Report on Book AND MAgazine PAPER (1959).

${ }^{\text {se }}$ It is estimated that in 1958 the federal government purchased $\$ 43,700,000$, 000 of goods and services, while state and local governments purchased $\$ 34,300$,000,000 worth. These compare with a total gross private product of $\$ 361,000,000,000$. EcoNOMIC REPORT OF THE PRESIDENT 143 (1959).

${ }^{57}$ See testimony of Walter Adams, Hearings Before the Subcommittee on Antitrust and Monopoly of the Senate Committee on the Judiciary, 86th Cong., 1st Sess., esp. 4785 (1959).

${ }_{68}^{8}$ See EDWARDs, op. cit. supra note 47 , ch. 8 ; see also his testimony in Hearings, supra note 57, at 4806-07, and his letter to Senator Kefauver, id. at 4853 ; Berge, The Antitrust Laws: A Symposium, 39 AM. Econ. Rev. 691 (1949); STAFF OF THE Monopoly Subcomm. of the House Comm. on SMall Business, 79th Cong., 2D Sess., United States Versus Economic Concentration and Monopoly 512 (Comm. Print 1947). 
competitive forces and an increase in concentration. ${ }^{59}$ Others have said that competition has increased in recent years and that concentration is no problem..$^{60}$ However, flat assertions and the analysis of the deficient data that are available provide uncertain bases for policy formation. ${ }^{61}$ We badly need sharpened tools of empirical economic analysis that will provide more profound, continuing evaluations of the state of competition in major industrial sectors and in our society. We need to develop measurements of concentration that adequately portray economic power in the economy, in regions, and in markets. ${ }^{62}$

Similarly, we need to forge better tools to evaluate the effects of our antitrust activity. ${ }^{63} \mathrm{We}$ must find out whether the sum total of antitrust activity encourages competition, or merely changes some of the forms of business activity. ${ }^{64}$ In the latter case, we need to evaluate the desirability of these changes in form.

Unfortunately, current methods of evaluation make it tempting for any national administration to build up the appearance of active enforcement with only nominal accomplishment. The major gauges for measuring antitrust activity are the following statistics from the FTC and the Antitrust Division of the Department of Justice: cases instituted; proceedings in court or other process; cases the Government has won and lost; consent decrees and orders; and cases appealed. However, we do not have satisfactory evaluations of the significance of these work loads and accomplishments. We do not know what proportion of these cases affect important companies in significant industries, or unimportant com-

\footnotetext{
${ }^{\circ 0}$ General Dissent of Louis B. Schwwartz, in Atrorney General's National CoMMitTeE to Study the ANTitrust LAWs, Report 390 (1955).

${ }^{\circ 0}$ E.g., G. L. Mehren, Bigness-Goodness or Badness?-In Those Who Feed Us, address before the Commonwealth Club of California, Nov. 7, 1958. See EDwards, op. cit. supra note 47 , at 318, who feels that American competitive policy has had substantial effect, bnt who feels that there are substantial gaps "between aspiration and performance." For surveys of studies in the field, see Heflebower, Monopoly and Competition in the United States of America, in CHAMBERLIN (ED.), MONOPOLY AND-COMpetition and Their Regulation (1954); and Mason, Economic Concentration and the Monopoly Problem ch. I (1957).

'1 "No sort of an estimate concerning the comparative extent of competition and monopoly in American markets is justified by the available evidence." Wuccox, op. cit. supra note 30 , at 308 .

${ }^{62}$ See Edwards's testimony, Hearings, supra note 57 , at 4809 .

${ }^{03}$ See AtTorney General's National Committee to StUdy the Antitrust LAWs, REPORT 366 (1955); Report of the Committee, in WhITNEx, 2 ANTITRUST Policies 44 (1958).

" For an organized effort at such a valuation, see WHIrNEx, op. cit. supra note 63 .
} 
panies in insignificant industries. Nor can we judge whether adequate attention is paid to trouble spots in the economy.$^{65}$

Unless we can attain more incisive analyses, it is difficult to see how well-intentioned people in our antitrust agencies can obtain firm support for realistic enforcement of our antitrust laws. Without such analyses, Congress does not have a firm basis for determining what resources are required for the effective application of our antitrust laws. Are larger budgets necessary, or will they lead only to that proliferation of bureaucratic empires which would provide further illustrations of Parkinson's law?

\section{Analysis of Effects of Types of Decrees}

Related to this over-all evaluation is the need for specific analyses of the effects of court decrees and FTC orders. As pointed out earlier, general language is employed in antitrust statutes in order to permit the administrative agencies and the judiciary to develop the law case-bycase. This reason implies an experimental approach that should call for a close examination of results. But we experiment without examining the results. We have no organized program for reviewing the competitive effects of individual decrees and orders. We do not know which types of decrees promote competition in what types of business situations.

The need for such reviews is illustrated by the Standard Stations case. ${ }^{66}$ The Supreme Court held that Standard Oil of California violated the Clayton Act when it entered into agreements which provided that retail gasoline stations would purchase all of their gasoline, tires, batteries, and accessories from Standard. Therefore, those agreements had to be canceled. In a dissenting opinion, Justice Douglas raised a

\footnotetext{
${ }^{65}$ The necessity for employing economic analysis to determine where to allocate enforcement efforts was stressed in a review of antitrust enforcement which was commissioned by Judge Victor Hansen, then Assistant Attorney General in charge of the Antitrust Division. The full report of Dean E. T. Grether and Professor Carl Kaysen, the economists who conducted the review, was not published. However, a short mimeographed summary of their report was released. They seem to have stressed the need for giving economists and economic analysis "a large role at the policy level." The Attorney General's National Committee to Study the Antitrust Laws felt that some experienced staff lawyers and economists should be assigned solely to advise the Assistant Attorney General regarding the advisability of instituting proceedings against individual companies. ATtORNEY General's Natronal COMmitTEe to StUdY the ANTITRUST LAWS, REPORT 359 (1955). The Report says further, "Some have urged that the Division on occasion, in anticipation of pretrial settlement, has brought weak cases." Id. at 360 . See also Staff of Subcomm. No. $x$, House Select Comm. on Small Business, 85Th Cong., 2D Sess., LaW Enforcement Activities Affecting Small Business 3, 5 (Comm. Print 1959).

${ }^{\circ 0}$ Standard Oil of California v. United States, 337 U.S. 293 (1949).
} 
troublesome query regarding the effect of such a holding on the objectives of our antitrust policy. He argued that such a decree would induce a large company to establish stations of its own instead of selling to independent retailers. Justice Douglas felt that even though the retailer might have to deal with one producer, under such an agreement, he could maintain a degree of independence, which is quite important politically. He contrasted this with the dependence of employees of Standard who would run the same gasoline stations. Therefore, he expressed considerable doubt about the majority decision, which was regarded by some as a rather strict interpretation of the Clayton Act.

Now, we have here a strong position taken by a man who is known to be deeply in favor of competition; ${ }^{\mathbf{6 7}}$ a man with wide experience in the executive and judicial branches of the Government; one whose opinion cannot be lightly dismissed. Nevertheless, we have no mechamism for testing the question he raised, since no one bears the responsibility for observing the effects of decrees. ${ }^{68}$

Without a continuing review of the effects of decrees, we have no way of judging what types of decrees will provide constructive remedies for any type of antitrust violation. We have theories, but we have no empirical data. Therefore, though the formulation of a decree calls for forecasts of the effects of various alternatives, we have practically no guideposts based upon past experience.

This requirement for review calls for a discriminating analysis. It would be fruitless to seek the one type of decree that would be effective in every situation. We need incisive studies that differentiate between various types of market conditions. With such analyses, the antitrust agencies and the courts could perform their tasks more effectively and we would have firmer policy guides.

${ }^{67}$ Countryman (Ed.), Douglas of the Supreme Court esp. ch. 3 (I959). See also Stocking, Economic Change and the Sherman Act: Some. Reflections on "Workable Competition," 44 VA. L. REV. 537, 582 (1958).

${ }^{\circ 8}$ The Attorney General's National Committee to Study the Antitrust Laws points out that the Antitrust Division is "responsible for the enforcement of some 378 judgments entered since I890" up to I955. It found that despite occasional campaigns compliance has usually been investigated only after complaints are received. ATTORNEY General's National Committee to Study the Anttrrust LaWs, Report 366 (1955). For an interesting attempt by a judge to consider the effect of a decree, see Judge Wyzanski's "Opinion on Remedy" in United States v. United Shoe Machinery Corp., I ro F. Supp. 295, 352, 354 (D. Mass. 1953). He proposed trying "milder remedies" first with a provision: that both parties "report to this Court the effect of the decree" ten and a half years after termination of an appeal; and that either party could then propose a modification of the decree. 


\section{E. Consent Orders and Decrees}

The need for broad economic analysis of the effects of antitrust enforcement is enhanced by the extensive use of consent orders and consent decrees. ${ }^{69}$ Under the consent procedures, there are no trials of the issues of fact or of law in either the courts or in hearings before trial examiners at the FTC. The consent order or decree is formulated in closed-door negotiations between the lawyers for the defendants and the lawyers for the antitrust agency. There is no public record spelling out the reasons for filing a complaint, nor the basis for the decree. Neither the general public, lawyers, nor economists have an opportunity to examine fully the backgrounds for the consent decrees or orders.

The extent of this practice has not been widely recognized. During the last five years, the consent procedure accounted for approximately eighty-eight per cent of the civil decrees rendered in prosecutions by the Antitrust Division. ${ }^{70}$ Roughly three-quarters of these consent decrees were negotiated by the parties before the Division filed a complaint. ${ }^{71}$ During the same period, about seventy-one per cent of the cease and desist orders issued by the FTC were negotiated, while four per cent of the orders were issued when the respondents offered no defense. ${ }^{72}$ In effect, roughly seventy-five per cent of the FTC's cease and desist orders were issued without public hearings.

When the Department of Justice negotiates a consent decree before filing a complaint, the public record probably does not disclose the full reasons for the prosecution. Since the complaint is filed after the consent decree has been agreed upon, the Department naturally would not

${ }^{69}$ See Kramer, Modification of Consent Decrees: A Proposal to the Antitrust Division, $56 \mathrm{MICH}$. L. REv. $105 \mathrm{I}$ (1958), for a description of the extensive effects of consent decrees.

${ }^{70}$ From 1954 to $195^{8}$, inclusive, the Antitrust Division won 144 civil cases in the district courts. During the same period, the Division terminated 127 cases by consent judgments. Figures were tabulated from information supplied by Victor R. Hansen, Assistant Attorney General.

${ }^{71}$ Barnes, The Department of Justice and the Antitrust Laws, in VAN CISE, UNDERSTANDING THE ANTITRUST LAWS I25 (1955). "From 1935 to I 945 approximately 109 antitrust actions ended in consent decrees. Of these 79 were entered within three days after the complaint was filed." Id. at 133. In the second half of the 1920's, prefiling negotiation was employed by the Antitrust Division in about 25 percent of the cases. Id. at 135 .

${ }^{72}$ From 1954 to 1958 , inclusive, the FTC issued 834 orders. Five hundred and ninety-six orders were issued with the consent of respondents; 31 orders were issued after respondents defaulted or filed admission answers, and the remaining 207 orders were issued after a contest. Figures were tabulated from information supplied by the FTC. See Anderson, Settlement and Compliance Procedures, in 14 AMERICAN BAR Association Antitrust Section Report, Proceedings at the Spring Meeting 6o (1959). 
allege any charges which are not covered by the decree. Therefore, there is no public record of any potential charges that are not reflected in the decree. ${ }^{73}$

Without a continuing review of the consent orders, their backgrounds and their effects, neither Congress, the Executive, nor the public can have a satisfactory basis for evaluating the effects of our antitrust administration. Without such a review, the present procedure can tempt the antitrust agencies to play a "numbers game" in response to pressures from Congress and other sources for a militant prosecution of the antitrust laws. The consent procedures make it relatively simple to show a substantial record of prosecutions.

Without an adequate review of consent orders and decrees, there is little assurance that all prosecutions involve substantial issues. There have been prosecutions of small companies, in insignificant industries, which have consented to rigorous decrees and orders simply to avoid the great costs of litigation. A reasonable defense entails not only high court costs and legal fees, but also a great deal of the time and energy of important company executives, not to mention expensive preparation of material in operating departments. Therefore, a small company literally cannot afford to carry on the active defense of an involved case. Hence, without some safeguards, the antitrust agencies can be so busy with unimportant consent orders and decrees that the more important competitive problems in the economy are neglected. ${ }^{74}$

Extensive use of consent procedures can give rise to broad issues of equity in government regulation. Our legal system is designed to provide safeguards against undue prosecution and undue penalties. Among those safeguards are provisions for public hearings and other procedural restraints on administrative agencies. ${ }^{75}$ Since the Antitrust. Division is an executive agency, it is not confined by these restraints. Yet, it is diffcult to distinguish between its consent procedures and those of the FTC. In effect, the Antitrust Division operates as an administrative agency, ${ }^{76}$

\footnotetext{
${ }^{23}$ See the Schwartz dissent, supra note 59 , at 390 .

7 See Staff of Subcomm. No. I, House Select Comm. on Small Business, 85 Th Cong., 2D Sess., LaW ENForcement ACtivities Affecting SMall Business 15 , 2 I (Comm. Print 1959). The Attorney General's National Committee says that some feel that the Antitrust Division would be more selective in its cases if it had to try each case. However, the Committee disagreed with this point of view. AtToRney General's National Committee to Study the Antitrust Laws, Report 360 (1955).

${ }^{70}$ See Prettyman, Trial By Agency (1959). The procedural restraints are reflected in the Administrative Procedure Act, 60 Stat. 243 (x946), 5 U.S.C. § 1006 (c) (1952).

${ }^{20}$ "In drafting and negotiating consent decrees, the Antitrust Division is not in the
} 
without the limitations provided by the procedural safeguards erected around our administrative agencies. Further, because of the pressures of heavy defense costs and the fear of treble-damage suits, the defendant is frequently caught in a bad corner during the closed-door negotiations with either agency. Meanwhile, the agency's position is often formulated by lawyers who are overly-enthusiastic about the "chase" at lower levels and who are not reined-in by a thorough policy review in the upper levels. This situation has, on occasion, produced orders and decrees that appear to be considerably harsher than those which would have been entered by the Commission or by a judge after an open hearing. ${ }^{77}$ Since the procedural restraints on administrative agencies are focused on public proceedings, they have little effect on the consent procedures in the FTC and no influence on the work of the Antitrust Division.

On the other hand, some have felt that there have been consent decrees and orders which were too soft. It has been suggested that in some instances, a court or hearing examiner would have imposed a tougher order; further, that the lawyers supporting the complaint would have presented stronger cases in public proceedings than the consent orders seem to imply. ${ }^{78}$

These deficiencies do not necessarily make it desirable to eliminate consent decrees. Consent procedures of some type are vital in the enforcement of our antitrust laws. ${ }^{79}$ As we shall see, public antitrust pro-

position solely of a litigant in a law suit; rather it must necessarily assume many of the attributes of an administrative tribunal." Kramer, supra note 69, at 1066.

${ }^{77}$ See Watkins \& Dirlam, Government Policy Toward Competition and Private Pricing, in The Relationship of Prices to Economic StabilitT AND GrowTH 5 I3 (1958). See also Peterson, Consent Decrees: $A$ Weapon of Anti-Trust Enforcement, I 8 U. KAN. CiTY L. REV. 34 (1950).

${ }^{78}$ Staff of Subcomm. No. 5, House Comm. on the Judiciary, 86Th Cong., ist Sess., Consent Decree Program of the Department of Justice (Comm. Print 1959). See also Hearings Before the Antitrust Subcommittee No. 5 of the House Committee on the Judiciary, 85th Cong., 2d Sess. (1958), especially the testimony of Victor H. Kramer, former Chief of the Litigation Section of the Antitrust Division. Kramer makes the point here, as well as in his article, supra note 69 , that consent decrees curtail the Antitrust Division's power to prosecute the defendants for antitrust reasons, since they "settle" the relief which can be granted for activities up to the time of the suit. For a further discussion of this point see Dabney, Antitrust Consent Decrees: How Protective an Umbrella?, 68 YALE L.J. I39I (1959). See also STAFF of SuBcomm. No. I, House Select Comm. on Small Business, 85Th Cong., 2D Sess., Law Enforcement Activities Affecting Small Business 16 (Comm. Print 1959).

${ }^{70}$ Stanley N. Barnes states the case for consent decrees in Settlement by Consent Judgment, in Section of ANTitrust LaW, AMERICAN Bar Ass'N, AN ANTitrust HandBook 235 (1958). Hamilton \& Tils, ANTitrust in Action 88 (TNEC Monograph No. 16, I940), argue that the consent decree can he more meaningful than 
ceedings are so extended that requiring such an adversary hearing in each case would place an intolerable strain on our administrative organization. $^{80}$ Such a burden would force either a substantial enlargement of the antitrust agencies, the courts, and the antitrust bar, or a drastic curtailment of antitrust activity.

Here, then, is the dilemma: on the one hand, the consent procedures are necessary for effective enforcement; on the other hand, they can lead to injustice, they can induce an agency to overlook important problems because it is busy building a paper record of accomplishment, they can provide remedies which fall short of the mark, and they provide a curtain which removes the proceedings from public scrutiny. To pose this dilemma is not to deny that we have a number of capable fairminded men in our agencies, men who are anxious to promote fair, rigorous applications of our antitrust laws. Rather, the issue is: what can be done to assist these men in their goals and to provide more significant policy evaluations of the operations of our antitrust agencies and the effects of our antitrust laws. Until some process is developed to meet this need, a most significant opportunity to apply the tools of economic analysis in policy formation will be foreclosed.

\section{III}

\section{Administration}

From a broad institutional view, there are a number of participants in the administration of our antitrust laws. The federal agencies include the Antitrust Division of the Department of Justice, and the Federal Trade Commission as well as a number of other agencies, such as Department of Agriculture, Federal Reserve Board, Interstate Commerce Commission, and Federal Communications Commission. The Federal District, Appeals, and Supreme Courts are important participants. In this context, many lawyers have significant roles in the administration, whether they represent the Government, plaintiffs in treble-damage suits, or defendants.

If it is to be effective in the field of competition and monopoly, economic tools of analysis must fit into the framework of this administrative structure. The mere transfer of methods of economic analysis that

litigated decrees because they "can attempt to shape remedies to the requirements of industrial order."

${ }^{80}$ As early as 1941, it was estimated that the government's costs in litigating an antitrust case ranged from $\$ 100,000$ to $\$ 150,000$. HANDLER, A STUDY OF THE CONSTRUCTION AND ENFORCEMENT OF THE FEDERAL ANTITRUST LAW 92, (TNEC Monograph No. 38, 1941). 
are useful in policy formulation will not meet this need. The methods for applying analyses differ, as do the advisory needs.

One of the road-blocks against the practicable use of economic analysis in anti-trust administration is a confusion between the roles of the economists in policy-making and in administration. During the process of legislative policy formulation, the economist is expected to engage in free-wheeling analysis, free of the fetters of existing regulation. Current laws and their administration are operating data that he must cover in his analysis; they are not restrictions. Indeed, at the legislative level, the economist can use the lawyer to assist in supplying legal interpretations and in legislative drafting.

In contrast, the lawyer runs the administrative show. Here, the economist is the assistant, aiding the lawyer in ideas, preparation of material, and analysis. Here, the economist must accept the limits of the existing law and operate within them. ${ }^{81}$

This distinction has been stated rather baldly here in order to point up the differences in the functions. Obviously, the differences are not black-and-white. They are found in varying shades of gray. Since policy formulation is not confined to the Congress, economists have to advise lawyers on policy on many occasions. Thus, they must be prepared to advise the lawyers who are called on for legislative recommendations.

However, the main point remains. Economists frequently confine their analysis unnecessarily, within the limitations of existing law, when they discuss policy. On the other hand, they frequently fail to recognize the task of the lawyer in the administration of current regulation and overlook pertinent operating problems.

Let us illustrate the differences in the application of economic analysis in policy-making and in administration. When the Robinson-Patman Act was under consideration, there was concern lest the Act stifle marketing innovations that might lower distribution costs. As will be recalled, the Robinson-Patman Act is aimed at price differences that may injure competition. Some members of Congress wanted to be sure that the Act would not restrain low-cost methods of distribution, even though they might hurt those competitors who followed the older methods. ${ }^{82}$

${ }^{81}$ In this connection, the economist's role is no different from that of the judge or lawyer. See Judge Lindley's comment about the functions of the judge in Corn Products Refining Co. v. FTC, 39 F.T.C. 664, 669-70 (1944): "When a standard of conduct has once been fixed by legislative enactment, the only functions of the judiciary, as a coordinate branch of government, are so to interpret the statute as to promote and effectuate the disclosed intent of Congress."

${ }^{82}$ For an excellent discussion of the legislative background of the Act, see EDWARDs, 
To avoid this danger, the law permitted a seller to pass his cost savings on to his lower-cost customers. For example, if a food packer's costs in selling to supermarket chains were lower than in selling to small retailers, he could sell to the chain at discounts which were as large as his cost savings, even though competing small grocers might be hurt.

Now, at the time the Act was under congressional scrutiny, most economists working in the field were convinced that the provision for cost justification of lower prices was not practicable. ${ }^{83}$ Both the economists and the cost-accountants knew that techniques of cost-accounting were not definitive enough to make this cost justification a tolerably workable defense. In fact, there was agreement that conventional costaccounting methods produced data on average costs, and not on cost differentials; that costs of distribution and administration, the principal areas in which such cost differences might be found, were regularly treated as average percentages of sales volume; therefore, cost differentials could not be readily measured by ordinary industrial costaccounting. ${ }^{84}$ Incidentally, many economists were concerned about this provision because they feared that it might be an opening wedge for a policy of price-setting by cost formulas. At any rate, it seemed clear to these economists that the cost proviso was not a practicable tool to avoid a tendency to freeze methods of distribution if the Act were enacted.

Conceivably, if Congress had been given a clear understanding of the impracticability of the cost proviso, many legislators would have been concerned about the law's effect on lower distribution costs. They might have voted against the bill, and it might not have passed.

Here, then, we have an example of the basic difference between economic analysis in policy-making and in administration. When the Robinson-Patman Act was under consideration, the tools of economic

Price Discriminations LaWs: A Review of Experience (the Brookings Institution, 1959).

${ }_{88}$ This lack of practicality has been reflected in administration. The then Chairman of the FTC, Edward F. Howrey, said that "the fact remains that the cost defense has proved largely illusory." Quoted in TAgGaRT, Cost Justification 533 (1959). The same position was taken by the ATTORNEY General's NATIONAL COMMITTEE TO STUdy THE ANTItrust LaWs, REPoRT i 7 ( 1955 ). It is interesting to note the differences in the treatment of costs by the FTC and the Canadian Restrictive Trade Practices Commission. The Canadian agency regards cost proof as a much less precise activity than does the FTC. See the Report Concerning THe Wholesale Trade in Cigaretrtes and Confectionery in the Edmonton District (1958).

${ }^{84}$ Massel \& Gornley, Business Methods and Antitrust Policy: The Automatic Canteen Case, I ANTrTrust Bul. 36r, 467 (1955). For a detailed discussion of the applications of cost accounting in FTC cases, see TAGGART, op. cit. supra note 83 . 
analysis relating to cost structures and cost behavior should have been brought to bear on the policy issue. Such analysis would have called for a strong stand regarding the impracticability of the cost defense. However, when the law was passed, the economist's help was needed to develop methods of measuring cost differentials as an aid to the lawyers for the FTC and the respondents, and to the courts. At that stage, preoccupation with the argument against the cost proviso would foreclose the usefulness of economic analysis as an affirmative aid in administration.

If he is to participate in administration, the economist must accept the limits of existing law. Such acceptance by the economist engaged in administration does not, of course, imply that economists generally should overlook the importance of continuing to review the effects of the law and its administration in considering policy issues-such as the continuation or the enforcement of the law.

\section{A. Analytical Tools Must Be Operational}

The economist's tools must be operational within the framework of the legal system to be useful in the field of antitrust. ${ }^{85}$ Otherwise, many lawyers will cling to their general argument that economists do not offer practical help..$^{86}$

In litigation, economic tools of analysis must fit within the context of the lawyer's methods for considering antitrust problems. ${ }^{87}$ If they are to be utilized by lawyers, they cannot require direct application of a rounded structure of economic theory. ${ }^{88}$ Thus, it does not seem pos-. sible, in the near future, to get courts or administrative agencies to use

\footnotetext{
${ }^{85}$ See Markham, Economic Analysis, in Section of Antrtrust Law, AmERICaN Bar Ass's, An Antitrust HandBook 373 (1958).

${ }^{s B}$ See, e.g., Howrey, Coalescence of Legal and Economic Concepts of Competition (1955). For an amusing statement of a general attitude towards economists, sce Gordon, Walking Backward Into the Future, in How to COMPLT WITH THE ANTITRUST LAWs 45 (1954).

${ }^{87}$ Stocking suggests that some technical economic concepts require the skill of an economist and may not be of unuch use in the hands of a judge. See his specific point regarding "cross-elasticity" in this connection. Stocking, Economic Change and the Sherman Act: Some Reflections on "Workable Competition," 44 VA. L. REv. 537, 570 (1958).

${ }^{88}$ Yankwich, "Short Cuts" in Long Cases, I3 F.R.D. 41, 58 (195I): "I am of the view that while economic facts have a place before the court in these cases and an economic expert might help summarize them, and, if the situations are very complicated, give his opinion as to the inferences to be drawn from them, economic theories are out of place in the average anti-trust case." For a discussion of economic inference, see Standard Oil Co. v. United States, 337 U.S. 293, 309 (1949); Timberg, The Rights of Customer-Seller Selection, in Commerce Clearing House, Business Practices Under FEDERAL ANTITRUST Laws 150 (1951); Lockhart \& Sacks, sispra note 7.
} 
a fully-defined model of competition in an industry as a yardstick. Few lawyers, if any, would offer a systematic presentation of such a model in order to establish the presence or absence of adequate competition. As a matter of fact, economists have themselves been long on discussing this method in theory and short on applying it in industry studies.

Economists must appreciate the legal setting of a trial in order to understand the evidentiary problems. ${ }^{89}$ Otherwise, economic analysis, which may be first-rate, may fall wide of the mark. Similarly, they must recognize that there are cases that do not call for any economic analysis even though the subject'matter of the case may have substantial economic effects. For example, in the General Motors Acceptance Corporation case, ${ }^{80}$ the charge was that GM and GMAC had conspired to restrain trade in violation of the Sherman Act by forcing automobile dealers to finance customers' paper through GMAC. The Government produced several dealer-witnesses who testified that they had been coerced. The defendants sought to bring in dealer-witnesses to prove that most dealers had not been coerced and that competition had not been restricted. The court refused to listen to the defense witnesses on the ground that the Government's witnèsses showed that a conspiracy existed, even though they were the only ones who were coerced. In effect, no economic evidence of effective restraint of trade was required to support the Government's charges of conspiracy to restrain trade, though it would have been essential to: support a charge that trade had been restrained. Thus, the intent to restrain was the central feature of the case, rather than the possible success of the attempt.

Another difficulty in applying economic analysis, arises because the economist and the lawyer frequently use the same. words, but with

\footnotetext{
${ }^{80}$ For discussions of the rules of evidence, see Yankwich, supra note 88; Dession, The Trial of Economic and Technological Isstes of Fact, 58 YALE L.J. Ior9 (1949); McAllister, The Judicial Conference Report on the "Big Case," 38 A.B.A.J. 289 (I952). The rules of evidence have been "liberalized" by many courts in their consideration of economic data. Thus, "The relevant political and economic facts can be presented to the Court in an informal way. It is not necessary to comply with those minimal standards of evidentiary competence suitable for the proof of other types of fact even in the comparatively loose procedure commonly followed in a civil antitrust case where the Government seeks an injunction." United States v. Minnesota Mining and Mfg. Co., 92 F. Supp. 947, 958 (D. Mass. r950). For a discussion of the rules as they apply to administrative agencies, see Administrative Procedure Act, 6o Stat. 243 (x946), 5 U.S.C. $\$$ roo6(c) (1952); Legislative History of THE Administrative Procedure ACT (ig46); AtTorney General's Committee to Study Administrative ProCEDURE in GOVERNMENT AgENCIES, REPORT ( $194 \mathrm{~T}$ ).

${ }^{90}$ United States v. General Motors Corp., r2I F.2d 376 (7th Cir. 194I).
} 
different meanings. ${ }^{01}$ Take, for example, the term "price discrimination." In economic theory, price discrimination covers undue similarities as well as undue differences in price. ${ }^{92}$ Thus, a manufacturer who sells to two customers at the same price would discriminate if there were differences in his costs of selling to each of them. For in economic theory, any prices which do not reflect cost differences are discriminatory.

In contrast, under such regulations as the Robinson-Patman Act ${ }^{03}$ and public utility legislation, a price discrimination occurs when there is a difference in the prices charged to two customers who compete with each other. Thus, if the same price is charged to two customers, there cannot be a price discrimination under the Robinson-Patman Act, regardless of what differences there may be in cost.

Here, then, is the basic language problem: some price discrimination, as the economist defines it, will not fit the legal definition; some price discrimination, under the legal regulations, will not meet the economic definition; while some price differences would classify as price discrimination under both definitions.

\section{B. Opportunities to Apply Economic Analysis in Administration}

In the administrative process, there are several fairly distinct opportunities to apply the tools of economic analysis. ${ }^{04}$

Effective administration of our antitrust laws calls, first, for concentration on those industrial markets which require most attention. Antitrust agencies need to conduct a continuing review of the economy in order to identify those industrial sectors in which competitive influences

\footnotetext{
${ }^{91}$ AtToRney General's National Committee to Study the ANTITRUSt LaWs, REPORT $3 \times 6$ (I955).

${ }^{93}$ Enwards, Matntaining Competition (1945). For a discussion of the concept in economic theory, see Clemens, Price Discrimination and the Multiple-Product Firm, 19 REV. ECON. STUDIES I (I95I-52); ROBINSON, ECONOMICS OF IMPERFECT COMPETITION chs. I5, I6 (1936). For a description of the types of discrimination, see Machlup, op. cit. supra note 46, at 137-68; Cassady, Techniques and Purposes of Price Discrimination, II J. MARKETING 135 (1946).

${ }^{93} 49$ Stat. 1526 (1936), 15 U.S.C. $\$ \S 13,13 \mathrm{a}, 1_{3} \mathrm{~b}, 21 \mathrm{a}$ (1952).

${ }^{24}$ It might be noted, parenthetically, that this discussion is confined to equity procedures which lead to an order governing future activity. We are not covering criminal procedures, with or without a jury, or private treble damage actions. Though there are a number of differences between the equity procedures and the criminal or damage cases, the role of economic analysis is roughly the same in all three types of legal actions, except for the determination of a remedy. In treble-damage actions, the proof of damages calls for another economic analysis. After a criminal conviction, the judge may set a fine, or in very rare instances, a prison sentence; neither penalty calls for economic analysis.
} 
seem to be inadequate. ${ }^{95}$ In this review, measurements of concentration and criteria for gauging competitive conditions would be applicable. However, there are few public indications that our antitrust agencies have employed economic analysis to that end. By and large, except for merger cases, the antitrust agencies seem to institute their investigations only after they receive protests from the public. ${ }^{96}$

After a decision has been made to investigate a market, economic analysis can be applied to find out whether there may be a violation of the antitrust laws. Such a review calls for a determination of what are the anticompetitive influences, what antitrust statute has been violated, how good a case can be made, and what practical means there may be for stimulating competition.

During the negotiations of a consent decree or order, the lawyers for each side can use economic analysis to evaluate the strength of the Government's case and the probable effects of a proposed decree.

During the course of the trial, as we shall see, economic analysis can help to determine whether there has been an antitrust violation and to formulate a decree which will cure the violation and stimulate competition within a market: ${ }^{97}$

Lastly, on the government side, economic analysis could be profitably employed to review the effects of past antitrust proceedings. Such analysis would enable the agencies and the courts to evaluate the relative merits of various types of decrees.

\section{IV}

\section{Trial Procedures}

A quick look at the mechanics of the trial of antitrust cases may illustrate the nature of these general observations about administration. An appreciation of these trial procedures is a prerequisite to an understanding of the size, scope, and nature of economic analysis as a realistic aid in antitrust administration.

To begin with, one must consider the conceptual framework of the judicial process. This process is essentially one of selection. The judge's primary function is to make choices regarding facts and law. on the basis of the evidence and the legal arguments presented to him in open court. It is presumed that each adversary before the court will

${ }^{95}$ For a similar proposal see HANDLER, op. cit. supra note 80 , at 96 .

${ }^{\circ 0}$ HANDLER, op. cit. supra note 80, at go; HAMILTON \& TilL, op. cit. supra note 79, ch. 3 , contains an interesting description of "The Origin of the Suit."

${ }^{\circ 7}$ HAMILTON \& TILL, op. cit. supra note 79, at II3, feel that it is not sufficient to employ economists in this task. "The need is a round of skills shaped to the task.". 
present the strongest evidence and arguments on his side. The judge is expected to base his decision solely on the presentations made by the adversaries. He does not strike out, on his own, to investigate other data or other legal theories.

This procedure puts each adversary on notice of the evidence and the legal arguments that the judge has under his consideration. Therefore, if $A$ hears $B$ present evidence or legal arguments which are unfavorable to $A$, he has full opportunity to present evidence or arguments to counter the unfavorable material. Such an opportunity would not be available if the judge were to conduct his own private investigation. This open procedure is so firmly imbedded in our judicial traditions that many legal scholars feel that our respect for the courts depends on it.

This theory of the judicial process is implemented by the various stages of an antitrust trial: ${ }^{88}$ first, the definition of the issues of the trial; second, the collection of data; third, the presentation of the data, within the rules of evidence and court procedure $;^{90}$ fourth, the presentation of arguments by the lawyers analyzing the data and the law in the light of the issues presented; fifth, the judicial sifting and determination of conclusions regarding the violation; and finally, the formulation of the decree 'if a violation has been found. In some instances, and these are becoming more common, decrees call for continuing judicial supervision of certain behavior of the defendants after the trial. At each stage, there are definite opportunities to employ economic analysis effectively.

The starting point for an antitrust trial is, of course, the definition of the issues. During this phase, the pleadings are presented. In some instances, trial briefs outline the evidence which will be presented. Pretrial conferences ${ }^{100}$ may be held between the judge and the counsel

\footnotetext{
${ }^{88}$ For an interesting review of the techniques of an antitrust trial, see Hollabaugh, Development of an Antitrust Cáse, in Section of 'AnTrtrust Law, AMERICAN BAR Ass'N, AN ANTITrust HandBook 24I (1958); Kramer \& Schueller, Pleadings, Interrogatories, Pre-Trial Conferences, Particularization of Issues, and Trial Briefs, id. at 255; O'Donnell, Civil Antitrust Trials, id. at $30 \mathrm{r}$.

${ }^{90}$ For an interesting description of the obstacles provided to the efficient trial of an antitrust case, see Corwin D. Edwards's description of the introduction of import statistics in the Aluminum case. Edwards, Can the Antitrust Laws Preserve Competition?, 30 AM. ECON. REv. I64 (1940). However, there are many signs of practical relaxation of some of the rules of evidence. See, e.g., FTC v. Cement Institute, 333 U.S. 683, 705 (1948); United States v. United Shoe Machinery Corp., I10 F. Supp. 295 (D.C. Mass. 1953).

${ }_{100}$ The purposes of pretrial conferences are set forth in the report of the Judicial Conference of the United States. The Report: Procedure in Antitrust and Other Protracted Cases, I3 F.R.D. 62, 72-73 (1951).
} 
for both sides to review the types of evidence that will be introduced at the trial, and agreements may be developed regarding specific evidence that will be acceptable to both sides. On occasion, both sides will stipulate certain evidence so that the length of the trial may be shortened. This phase of the trial frequently is of major import for an adequate consideration of the economic issues. Many cases are lost by the plaintiff or defendant primarily because the economic issues were not clearly defined before the trial began. ${ }^{101}$

Before the start of the trial proper, the collection of data is the task at hand. During this stage, the tools of economic analysis can be used profitably for collecting data, handling problems of sampling, and developing statistical inference from the data. ${ }^{102}$ Important decisions have to be made regarding sources of information, both quantitative and nonquantitative, what published material can be used, how internal operating information can be employed, what special studies should be undertaken, and what information should be obtained through inquiry from the other side. Here, as in the definition of the economic issues, economic analysis can help to plan the strategy of the case. ${ }^{103}$

After the data have been developed, determining how best to present them can involve some interesting problems. As we all know, the presentation of complex economic data for easy understanding is an art in itself. It calls for such a combination of testimony, explanation, and visual aids that the judge who is not skilled in economic analysis can grasp the economic situation-or overlook it, depending on what the lawyer's strategy may be. ${ }^{104}$

When one side knows how the other will present its evidence, the economist can suggest ways and means for disproving or counteracting it. Sometimes, the other side's presentation is known before the trial proper starts: on other occasions, it is learned only in open court.

${ }^{101}$ Grether states this feature in terms of "economic evidence" and "economic argument." He points out the need for setting the "facts" in a "conceptual framework provided by economic conceptions. ..." Grether, supra note 5, at 58 .

${ }^{102}$ Society of Business Advisory Professions, Standards of Probàbility SAMpling for Legal Evidence (Current Business Studies No. 26, 1957). Deming, On Presentation of the Results of Sample Survey as Legal Evidence, 49 J. AM. STAT. Ass'N 814 (1954).

${ }^{102}$ See Grether, supra note 5 , for a discussion of the analysis of price behavior in this connection. Markham, supra note 85. Howrey, Economic Evidence in Antitrust Cases, address before American Marketing Association, June 14, x954.

${ }^{104}$ See Barnés, Quantitative Data and Sample Surveys as Evidence in Judicial and Administrative Procedures, address before Society of Business Advisory Professions, May 20, 1954. Early, The Use of Survey Evidence in Antitrust Proceedings, 33 WASH. L. REv. 380 ( 1958 ). 
Needless to say, in the presentation of the case, the economist can be used as an expert witness. However, many lawyers think of the economist solely as an expert witness, and they overlook the significant help that the economist can offer in planning the strategy of the case. ${ }^{105}$

\section{A. Circumstantial Evidence}

The trial of economic issues in an antitrust case almost always turns on indirect or circumstantial evidence. Rarely is an antitrust case tried on the basis of direct evidence alone.

Direct evidence is useful mainly in a trial which turns on simple, uncomplicated issues of fact. Consider, for example, the testimony in a murder trial of an eye-witness who saw the shooting. Here, it is possible to prove that a specific crime took place, through the direct testimony. Similarly, if a suit concerns a written agreement which was signed by the parties, the presentation of the contract and direct evidence that it was signed may be sufficient to establish the facts of the case.

However, antitrust cases are rarely tried on such direct evidence. ${ }^{106}$ If the complaint charges that there is a price-fixing agreement, a written contract that was signed by each party would be presented as direct evidence. However, the government lawyer who finds such a written agreement is fortunate, indeed. Usually, he can prove a price conspiracy only by presenting circumstantial evidence that supports an inference that there has been a price agreement. Further, if his case requires proof that competition has been lessened (which proof is not necessary if the charge is price-fixing), ${ }^{107}$ he cannot find any direct evidence of this phenomena, since the lessening of competition is an analytical conclusion.

The treatment of circumstantial evidence involves a rather interesting methodology, based upon the testing of a hypothesis. The plaintiff presents his hypothesis, for example, that competition has been lessened

${ }^{105}$ Carl Kaysen makes this point forcefully in his account, op. cit. suppra note 6 . The book reflects his experience as a "law clerk" to advise Judge Wyzanski who tried the case. Kaysen feels that neither the government nor the company had the advantage of an economic analysis of the industry in planning their offense and defense. He says, "At the present writing, the recently decided suit against the investment bankers, United States v. Henry S. Morgan, et al. (Civil No. 43-757, S. District of New York), is the only completed case known to the writer in which the defense was planned with the aid of economic analysis, ab initio. As yet, the use of economic analysis by the Government is rudimentary."

${ }^{100}$ It has been said, regarding onc antitrust element, that "conspiracies are seldom capable of proof by direct testimony and may be inferred from the things actually done." Eastern States Lumber Ass'n v. United States, 234 U.S. 600, 612 (1914). See also, Interstate Circuit v. United States, 306 U.S. 208 (1939).

${ }^{107}$ United States v. Socony-Vacuum Oil Co., 3 10 U.S. 150 (1940). 
because of certain market practices of the defendant. He then offers his factual evidence, through testimony and exhibits. In some instances, he offers opinions of expert witnesses regarding the validity of the information presented and its implications. On completing his evidence, his position is: (a) that his information is clearly compatible with his hypothesis; and (b) that this evidence is not compatible with any other hypothesis; or (c) that, while it might conceivably be compatible with another hypothesis, the possibilities are so remote that his hypothesis is the only reasonable one.

Now, consider the position of the defense. The defendant's counsel seeks to knock down the plaintiff's hypothesis. He may, in the unusual case, persuade the court that the plaintiff's evidence is not compatible with the hypothesis, without presenting any further evidence. More frequently, the defendant does produce evidence. He may undertake to disprove some of the evidence presented by the plaintiff by cross-examining the plaintiff's witnesses or producing other information that directly controverts the plaintiff's evidence; at that point, the defendant may argue that the believable part of the plaintiff's evidence is not compatible with his hypothesis. Or, the defendant may introduce additional evidence and argue that the total evidence is not compatible with the plaintiff's hypothesis. In some instances, in order to defeat the plaintiff's case, the defendant may argue that the evidence at hand is more compatible with a new hypothesis which would wreck the plaintiff's case.

It may be useful to illustrate this procedure. Suppose that the Department of Justice has alleged that several competitors conspired to fix prices in violation of the Sherman Act. ${ }^{108}$ The Department does not have a written contract and cannot produce direct oral testimony that there was a price agreement. It shows that several competitors, located at widely-separated points, submitted identical bids for "widgets" on a government contract at a price of $\$ 8.73445$ per gross, delivered in Washington, D. C. It shows further, that over a period of several years, the prices of each of these competitors were changed at approximately the

108 There has been a substantial discussion about a doctrine of "conscious parallelism" and about the use of basing points as circumstantial evidence of price conspiracy. See, e.g., Kittelle \& Lamb, The Implied Conspiracy Doctrine and Delivered Pricing, I5 LAW \& Contemp. Prob. 227 (1950); Sunderland, Changing Legal Concepts in the Antitrust Field, 3 Syracuse L. Rev. 60 (195 I) ; Economic INSTITUTE OF THE U.S. Chamber of Commerce, Delivered Pricing aNd the Future of American Business (1948); Special Comm. of the Section on ANTi-Trust Law, N.Y. State Bar Ass'N, Memorandum for the President's Committee on Business and Government ReLATIONS 50-54 (1950). 
same time. It argues that these events could not have taken place unless there had been an agreement.

The defendants deny the charge. They prove that the peculiar price of $\$ 8.73445$ is the mathematical result of applying a series of percentage discounts to list prices. They show that these are the largest discounts they allow to any customer; further, the industry has sold to the Government at its lowest prices since 1932, when a government purchasing agent induced a wholesaler to make a purchase for the Government with no mark-up. They prove that the industry has always sold its products at delivered prices that are uniform in every state east of the Rockies; that, while the prices of each company did move together, the first company to cut a price was not always the same; and that there were occasions when one company raised its prices but had to cancel the increase because other competitors did not follow suit. Further, the defendants account for less than seventy-five per cent of the volume of the industry. Therefore, they did not and could not control prices or enter into an effective price conspiracy. Hence, they argue that the evidence presented, taken as a whole, is compatible only with the hypothesis that competition set the industry's prices.

The judge must consider, on the one hand, the plaintiff's hypothesis that there was a price conspiracy and, on the other, the defendant's that prices were set by the free operation of a competitive market. He must test them by sifting through the evidence, considering what is more plausible and deciding which hypothesis is more compatible with this evidence. ${ }^{109}$ However, he cannot make a field investigation himself. He must base his decision on what has been presented in open court.

It might be noted, parenthetically, that the hypothesis-and-test method of considering circumstantial evidence is not unique. This essentially is the methodology used in empirical economic analysis. It rests on the same foundation as the methodology followed in the physical, the natural, and the social sciences. ${ }^{110}$

Since the treatment of circumstantial evidence requires formulating and testing hypotheses, the trial of economic issues in antitrust cases calls for the clear application of the methodology of economics. The stages of an antitrust trial, outlined above, with the definition of issues, presentation of data, and the analysis of the data in the light of the issues is

\footnotetext{
${ }^{208}$ For a discussion of standards for evaluating circumstantial evidence, see Dession, supra note 89 , at 1046 .

${ }^{170}$ For a general discussion of the use of hypotheses, see CoHEN \& NAGEL, AN INtroduction to Logic and Scientific Method (1934). See also Veblen, The Place of SCIIENCE in MOdERN Civilization (I92I).
} 
similar to the prosecution of empirical economic analysis. The formulation of a theoretical framework for the empirical investigation closely resembles the formulation of the theory of the case. The trial of the issues calls for adversary proceedings. However, the over-all shape of the trial presents an interesting parallel to economic studies of the same types of problems.

Before leaving this discussion of evidentiary procedures, it may be interesting to consider its connection with recent debates on the nature of antitrust rules of law. It may be recalled that there have been a number of complaints ${ }^{111}$ recently that the courts are applying too many per se rules in antitrust cases and too few "rule of reason" rules." Roughly differentiating, a per se rule does not require a court to inquire into the economic effects of a practice, while the rule of reason does so require. ${ }^{113}$ For example, if a price conspiracy is proved, one of the per se rules applies and the Government does not have to show that the price agreement may lessen competition. In contrast, if there is an attack on a corporate merger, the Government must introduce evidence to show that it may tend substantially to lessen competition or tend to create a monopoly.

Because of the reliance on circumstantial evidence in most antitrust proceedings, the contrast between per se and rule of reason has been somewhat exaggerated. ${ }^{114}$ Differences do exist, but they are not in the

\footnotetext{
${ }^{111}$ E.g., Oppenheim, Federal Antitrust Legislation: Guideposts to a Revised National Antitrust Policy, 50 MICH. L. REv. 1139 (I952); Lockhart \& Sacks, supra note 7 . Contra, Stocking \& Watkins, op. cit. supra note 22, ch. 9; Rowe, Borderland Issues in Court and Commission Cases Under Sections 2 and 3 of Clayton Act, in SEction of Antitrust LaW, American Bar Ass'N, Proceedings 60 (x956); Austern, The Su preme Court and Section 3 of the Clayton Act-The Standard Oil of California Decision, in ANTitrust LaW Symposium 43 (1950); Meriam, The Sherman Antitrust Act and Business Economics, in id. at 93.

${ }^{112}$ For a history of the development of the rule of reason, see Handler, The Judicial Architects of the Rule of Reason, Io AMERICAN BAR Ass'N ANTITRUST SEcTION, REPORT 2x (1957). For a brief discussion of the differences between the two rules, with a list of cases illustrating their application, see Oppenheim, supra note II I, at I I 50-52. See, also, AtTorney General's National Committee to StUdy the Antitrust Laws, REPORT ch. 1 and 390-91 (1955); HANDLER, op. cit. supra note 8o.

113 "'The true test of legality is whether the restraint imposed is such as merely regulates and perhaps thereby promotes competition or whether it is such as may suppress or even destroy competition. To deterinine that question the court must ordinarily consider the facts peculiar to the business to which the restraint is applied; its condition before and after the restraint was imposed; the nature of the restraint and its effect, actual or probable. The history of the restraint, the evil believed to exist, the reason for adopting the particular remedy, the purpose or end sought to be attained, are all relevant facts." Chicago Board of Trade v. United States, 246 U.S. 231, 238 (1918).

${ }^{114}$ See Mason, Market Power and Business Conduct: Some Comments on the Report of the Attorney General's Committee on Antitrust Policy, in Economic Concentration
} 
day-or-night category. Thus, in our illustration of a price-fixing case, there was no direct evidence; circumstantial evidence involved the structure of the market and the behavior of competition; in fact, it did not fall far short of the evidence needed to "prove" that competition was lessened. Proof of some per se violations can delve as deeply into economic analysis as proof of some rule-of-reason violations. ${ }^{115}$ This feature is not a complete negation of the differences between per se and rule of reason. It merely suggests that the contrast may have been overdrawn.

\section{B. The Judicial Burden}

The task of sifting evidence and relating it to the hypotheses constitutes a key element in the judicial function. ${ }^{110}$ Considerations of the arguments about the law is the other part. Frequently, economic analy* sis affects the interpretation of both statutes and judicial precedents. The distinctions between issues of law and fact are frequently fuzzy, especially when economic interpretations are involved. However, we are considering only issues of "fact" here, as if the distinction were clear. ${ }^{117}$

To appreciate the judicial burden in an antitrust trial, one must recognize the tremendous size of the task. ${ }^{118}$ Many proceedings pose such complex problems of economic analysis that the judge's task would be formidable even for an able, experienced economist. ${ }^{110}$ To illustrate the "physical" size of the task, here are some extreme examples.

AND THE Monopoly Problem 389 (1957). "On the other hand, the rule of reasoneven in its 'most reasonable' application-has never, in fact, examined very far into the effects of a challenged course of business conduct. At most it has pursued economic investigation one or two steps beyond the point at which per se would have carried it." Id. at 394.

${ }^{115}$ For a clear illustration of the need to analyze market effects in order to try a case of price fixing, see American Tobacco Co. v. United States, 147 F.2d 93 (6th Cir. 1 944), aff'd, 328 U.S. 78 I (1946). See also, Morton Salt Co. v. United States, 235 F.2d 573 (roth Cir. 1956).

${ }^{116}$ For a general discussion, see Dession, supra note 89.

${ }^{217}$ The problem in applying this distinction is developed in a comment by Lord Bramwell. "No evidence is given in these public policy cases. The tribunal is to say, as a matter of law, that the thing is against public policy and void. How can the judge do that without any evidence as to its effect and consequences?" Mogul Steamship Co. v. McGregor, Gow \& Co., [1892] A.C. 25,45 .

${ }^{128}$ McAllister, The Big Case: Procedural Problems in Antitrust Litigation, 64 HARv. L. REv. 27 (1950).

${ }^{110}$ Many judges feel strongly about this burden. Thus, Mr. Justice Jackson wrote, "I regard it as unfortunate that the Clayton Act submits such economic issues to judicial determination." Standard Oil Co. of California v. United States, 337 U.S. 293, 322 (1949). For an additional comment on the ability of judges to appraise economic data, see footnote 13 in Mr. Justice Frankfurter's majority opinion. 
The trial of the Aluminum Corporation of America case ${ }^{120}$ lasted over a period of two years and two months. During that period, the judge heard I 53 witnesses fill up 58,000 pages of testimony. In addition, he had to consider 15,000 pages of documentary evidence. ${ }^{121}$ Similarly, in the recent Pillsbury case before the FTC, the hearing examiner had to contend with $3 \mathrm{I}, 000$ pages of testimony.

Compare the size of these records with the material covered in a respectable industry study. Remember, however, that it is the rare judge who has had the benefit of an education in economic analysis. ${ }^{122}$ Further, in keeping with the general framework of the judicial function, the judge does not enjoy the economist's opportunity to discuss his ideas with other economists during the course of his study.

To develop more effective use of economic tools of analysis in such trials, we urgently need to devise ways to help our judges to develop skills of their own or to provide them with skilled assistance. Yet, this task is formidable. ${ }^{123}$

\section{Use of a Judge's Economist}

What would seem to be an obvious solution for this problem will not fit the needs of the situation. At first blush, it would seem reasonable to supply the trial judge with an economist who would review the evidence and consult with him. ${ }^{24}$ However, such a practice would

${ }^{120}$ United States v. Aluminum Co. of America, 44 F. Supp. 97, 104 (S.D.N.Y. I 941).

${ }^{121}$ McAllister, supra note 1 I 8, at 58. For some other interesting figures, see the article's discussion of United States v. Imperial Chemical Industries, Io5 F. Supp. 215 (S.D.N.Y. 1952); United States v. United Shoe Machinery Corp., I Io F. Supp. 295 (D. Mass. I953); Henry S. Morgan or Investment Bankers case. See also The Report: Procedure in Anti-trust and Other Protracted Cases, 13 F.R.D. 62 (1953).

${ }^{122}$ United States v. United Shoe Machinery Corp., 346 U.S. 894 (r 953 ). "Judges in prescribing remedies have known their own limitations. They do not ex officio have economic or political training. Their prophecies as to the economic future are not guided by unusually subtle judgment. They are not so representative as other branches of the government. The recommendations they receive from government prosecutors do not always reflect the over-all approach of even the executive branch of the governinent, sometimes not indeed the seasoned and fairly informed judgment of the head of the Department of Justice. Hearings in court do not usually give the remote judge as sound a feeling for the realities of a situation as other procedures do. Judicial decrees must be fitted into the framework of what a busy, and none too expert, court can supervise. Above all, no matter with what authority he is invested, with what facts and opinion he is supplied, a trial judge is only one man, and should move with caution and humility."

${ }^{123}$ For an interesting discussion of the judge's task, see Hamilton \& TILL, op. cit. stipra note 79, at 70-74.

${ }^{124}$ However, the Attorney General's National Committee to Study the Antitrust Laws did "not feel an independent staff of economic experts should be provided to assist courts in the trial of antitrust cases no matter how involved. The place of an economic expert 
run counter to the basic premises of the judicial trial, since it fails to give each adversary an opportunity to counteract any argument or evidence that has been presented to the judge.

During the trial of the United Shoe Machinery case, Judge Wyzanski, a jurist of outstanding ability, decided that he needed help on the complex economic issues of the case. Accordingly, he appointed Professor Carl Kaysen of Harvard University as his law clerk to advise him. There is no clear record of what happened between the judge and his "law clerk." However, one can only presume that the judge relied heavily upon the interpretations offered by a "clerk" of such capacity.

Unfortunately, this procedure overlooked a conflict with strategic elements in the judicial process. As pointed out before, the premise of our trial procedure is that the judge will base his decision entirely on the evidence and arguments presented to him in open court. Within narrow technical limits, he may take "judicial notice" of certain public information, available to anyone. However, he is not supposed to base his decision on any of his own library or field research, nor is he supposed to act on any advice which he has received outside the presence of the lawyers for both parties.

The basis for this rule is a keystone in the structure of our legal system, with its many protections against Star Chamber proceedings. It is based upon the premise that all judicial decisions should be openly made on the basis of open evidence. ${ }^{125}$ It is intended to afford each party a full opportunity to counter evidence or opinions that may hurt his cause.

If the trial judge takes under consideration some information or expert opinion that is not known to the adversaries before him, the party who may suffer has no opportunity to counteract that evidence or opinion. If the injured party had been aware of the opinion or evidence, he might have presented other data or arguments against it. Such an opportunity is not available to either party if the judge engages in private discussion with an economist.

Here, then, is another dilemma. Our judges, able though they may be as lawyers, do not, with few exceptions, have the background for effective use of these tools of economic analysis. Nevertheless, we ask

in antitrust trials is no higher than an expert in any field, namely, as a witness on the stand, where his opinions meet the test of analysis and cross-examination as well as of contradicting, supplementing or explanatory testimony." ATTORNEY GENERAL'S NAtional COMMITTEe to STUdy THE ANTITRUST LAws, RePort 366 (1955). Cf. proposal of Oppenheim that a staff of economists be set up for assignment to judges who request their assistance. Oppenheim, $A$ New Look at Antitrust Enforcement Trends, ANTITRUST LAW STMPOSIUM 83 (1950).

${ }^{125}$ Fuller, The Problems of Jurisprudence (1949). 
them to analyze long records of highly-involved economic data. On the one hand, we assume that they do need help. On the other hand, the considered advice of economists, which would be most helpful to them, does not easily fit into the framework of our judicial system. ${ }^{126}$

It is interesting to note a lecture given by Judge Wyzanski just about the time he had the United Shoe Machinery case under consideration. ${ }^{\mathbf{1 2}}$ In those lectures, he raised some questions regarding a judge's use of research which was not made available to the parties before the court. He suggested one possible solution which merits consideration: that, if a court uses material based upon outside work, the "better course may be to submit the material (to the parties) for examination, cross-examination and rebuttal evidence."

The difficulties of this problem are matched by its importance. Until practicable solutions are found, the effective utilization of tools of economic analysis in antitrust as well as other trials will be sharply limited.

\section{Formulating Decrees}

After a judge has decided that the antitrust laws have been violated, his next problem is to formulate a decree. At this stage, he should be able to consider economic evidence regarding the competitive effects of various alternative decrees. The trial is not a sporting contest governed by an umpire whose sole task is to name the winner. ${ }^{128}$ The goal of an equity case is not how to punish a violator, but how to inject more competition into a market. ${ }^{120}$

On the whole, it seems fair to say that the courts have had even less

${ }^{128}$ The problem has become so important that the Judicial Conference of the United States set up a committee, under Judge E. Barrett Prettyman, Chief Judge, Circuit Court of Appeals of the District of Columbia, to consider it. Among other recommendations, the committee suggested the submission of complicated questions to an expert or a panel of experts serving as special masters for the court. The issue of fact would be submitted to the special master or panel. Hearings would be held. The master or masters would make a written report to the court which would be subject to exceptions and argument by the parties. Procedure in Anti-trust and Other Protracted Cases, 13 F.R.D. 62, 80 (1953). A contrary view was held by the Special Committee of the Section of Antitrust Law of the American Bar Association, Streamlining the Big Case, in Proceedings at The ANNUal MeEting of the Section of ANTITRUSt LaW 212 (1958). See also, Sink, The Unused Power of a Federal Judge to Call His Own Expert Witness, 29 So. CaLIF. L. REV. 195 (1956).

${ }^{127}$ Wyzanski, $A$ Trial Judge's Freedom and Responsibility, 65 HaRv. L. REV. I281, $1295-96$ (1952).

${ }_{128}$ "There is no merit in the ceremony of finding a violation unless something like adequate relief is to be granted." Levi, supra note $I 7$, at 182 .

120 Rostow makes this point in comparing criminal and equity remedies. Rostow, supra note 15 , at 589 . For a discussion of types of decrees that set down rules for business behavior, see Marcus, Impact on Business of Antitrust Decrees, I I VAND. L. REv. 
economic guidance in formulating decrees than in finding violations. Similarly, lawyers for the antitrust agencies have had little economic advice in formulating consent decrees or orders. ${ }^{130}$

An indication of the importance of economic analysis in formulating orders can be found in three recent decrees which were issued after successful antitrust attacks on collusive pricing. ${ }^{131}$ In substance, each of these ordered individual companies to set prices on the basis of their costs, plus the margin of profit they desired, and "other lawful considerations." Economists generally associate this method of cost-plus pricing with monopolistic conditions. It may be recalled that similar formula pricing was written into many NRA codes. ${ }^{132}$

The most serious deficiency involved in the promulgation of such decrees is the fact that there is no agency to study their effects. In theory, such decrees are deficient, since they appear to foster monopolistic, rather than competitive, forces. However, it is possible that in practice, they may provide effective bases for promoting competitive pricing. Remember that these competitors had agreed on prices. If they were told merely to discontinue the agreement, each company

303 (1958). See also Report of the Committee, in WHITNEY, op. cit. supra note 63, at 443. Courts have enunciated this goal on a number of occasions. See, e.g., HartfordEmpire Co. v. United States, 323 U.S. 386, 435 (1945); United States v. National Ass'n of Real Estate Boards, 339 U.S. 485 (1950); Timken Roller Bearing Co. v. United States, 341 U.S. $593,603^{\circ}$ (195I). Justice Jackson said, "In an equity suit, the end to be served is not punishment of past transgression, nor is it merely to end specific illegal practices. A public interest served by such civil suits is that they effectively pry open to competition a market that has been closed by defendants' illegal restraints." International Salt Co. v. United States, 332 U.S. 392, 401 (1947). See Hamilton \& TilL, op. cit. supra note 79 , at 86 , discussing the technique of regulation: "It is slow, clumsy, inefficient; and it is usually a moral victory, rather than an industrial corrective, which a resort to law will yield."

${ }^{180}$ For an interesting discussion of the problem of formulating FTC orders, see Shniderman, Federal Trade Commission Orders Under the Robinson-Patman Acl: An Argument for Limiting Their Impact on Subsequent Pricing Conduch, 65 HARV. L. REV. 750 (1952). An excellent analysis of the problems of decrees under the antitrust laws and of their purposes is contained in Timberg, Equitable Relief under the Sherman Act, 1950 U. ILL. L.F. 629. Timberg's final conclusion: "Whether he wills it or not, the antitrust advocate, if he desires to make an adequate approach to problems of antitrust relief, becomes a practicing economist and a co-developer of public law and public policy." $I d$. at 658 . Levi, suggests the possible merit of setting up an office, with no regulatory functions, which could advise the courts on appropriate remedies. Levi, supra note I7, at 183 . See also KAYsEN, op. cit. supra note 6 , at 343-44.

${ }^{131}$ United States v. New England Concrete Pipe Corp., 1958 CCH Trade Cas. 73, 715 ; United States v. L.A. Young Spring \& Wire Corp., 1950-51 CCH Trade Cas. 64, 750; United States v. Gold Filled Mfrs. Ass'n, $1957 \mathrm{CCH}$ Trade Cas. 73, 105.

${ }^{182}$ For a description of these cost protections, see Nelson, Minimum Price ReguLATION UNDER CODES OF FAIR COMPETITION (1936). 
might continue its old prices "without agreement." The cost-plus order might jar the price situation enough to start a new pricing pattern in motion. Then, if "other lawful business considerations" were taken to mean that prices could be reduced to meet competition, a competitive situation might develop. It might be observed, parenthetically, that fears of Robinson-Patman prosecution might reduce the testing and probing of the market that seems to be the hallmark of competition in an oligopolistic industry.

The essential point here is that we should not continue to depend upon theoretical evaluations of these decrees. We require a mechanism for employing empirical economic tools to give us some analytical predictions of the effects of various types of decrees. ${ }^{133}$

An increasing number of antitrust decrees require some judicial supervision over a period of time. ${ }^{134}$ For example, we have the costplus decrees discussed above. Similarly, there are a goodly number of orders providing that patents should be licensed at reasonable royalties and allowing prospective licensees to petition the court to set the royalties. ${ }^{135}$ Again, in several recent cases, defendants were ordered to sell, ${ }^{136}$ as well as lease, certain types of machinery; the decrees specified the relationships between the sales prices and the rental rates charged for the same machines. In each such case, the affirmative action required of the defendant presupposes that the court will be available to supervise the action.

No mechanism has been established to aid the judges in this supervision..$^{137}$ In some instances, private petitioners can be expected to police

\footnotetext{
${ }^{133}$ For a general description of various types of decrees, see Kilgore, Antitrust Judgments and Their Enforcement, in SECTION OF ANTITRUST LAW, AMERICAN BAR Ass'N, AN ANTitrust HANDBOOK 340 (I958).

134 At least one decree provides for court supervision over prices as a regular procedure. United States v. ASCAP, 1950-5 I CCH Trade Cas. 63, 750. See ASCAP and the Antitrust Laws: The Story of a Reasonable Compromise, 1959 Duke L.J. 258; Timberg, The Antitrust Aspects of Merchandising Modern Music: The ASCAP Consent Judgment of 1950, 19 LAW \& Contemp. ProB. 294 (1954).

135 "Since the early forties, some ninety-odd antitrust judgments have contained provisions for compulsory licensing [of patents] at reasonable royalties." Marcus, The Impact on Business of Antitrust Decrees, I I VAND. L. REv. 303, 306 (1958). The decree in United States v. Hartford-Empire Co., 46 F. Supp. 541 (N.D. Ohio. 1942), modified, 323 U.S. 386 (1945), called for a rather complex pattern of setting royalty rates for patents, rental rates for machines, and prices for machines. After this long complicated procedure, the Antitrust Division provided, in consent decrees, that prospective licensees could ask the courts to set reasonable royalties.

${ }^{138}$ Mund, Refusal to Sell, I I VAND. L. REV. 354 (1958), lists a number of antitrust judgments which contain compulsory-selling provisions.

${ }_{187}$ "The court lays down the law; but it possesses no facilities for seeing that the
} 
the decrees by demanding patent licenses and complaining to the court if the royalties charged are unreasonable. In others, the Antitrust Division may keep tabs on the industry and petition the court to enforce its orders. ${ }^{138}$ However, there are few public signs that the Division has organized itself for such a surveillance. When the new petitions are filed, lawyers will "battle it out" before the courts in the same manner as in any trial. But, whatever may be the occasion for the new court proceedings, we are back to the basic need for making economic advice available to the courts.

\section{SUMMARY}

If economic analysis is to be applied widely in the field of competition and monopoly, its methods must be operational. While there has been some progress, these methods are not operational today.

In order to improve the utilization of economic analysis in antitrust, lawyers and economists will have to develop a clearer understanding of each other's methodology. The economist will have to acquire a more precise grasp of the judicial system and of the operational framework of the law. On the other hand, the lawyer will have to realize that the economist will not learn to operate within the legal framework unless he feels some pressure to do so because he is called upon for affirmative assistance. The lawyer must reach out for help before he gets it. Just as the economist has to improve his understanding of the legal framework, the lawyer has to work with the economist on a more realistic basis if he expects this progress.

The economist must recognize that in the administrative arena his analytical tools will be used by lawyers who have not been brought up on technical economic analysis. Lawyers are not skilled in the economic jargon, nor do they have much patience with economic models. Further, in their daily work they must operate within the bounds of the current state of the law-the statutes, the judicial opinions, the legal definitions of terms, and the judicial system.

The economist needs to differentiate more precisely between the

terms of its decree are carried out. . . Thus the problem is thrown back upon the enforcement agency which, save for the opportunity to invoke contempt, is exactly where it was before the trial began. Actually, the [Antitrust] Division as at present financed and staffed, is quite unable to undertake a task of such magnitudc. . . ." HAMILTON \& Till, op. cit. supra note 79, at 77 .

${ }^{238}$ In some instances, the Division has been given the right to ask for a modification of the decree or for additional relief. United States v. United Shoc Machinery Corp., 110 F. Supp. 295, 35 I (D. Mass. 1953); United States v. Aluminum Co. of America, 91 F. Supp. 333,419 (S.D.N.Y. 1950); United States v. Imperial Chemical Industries, 105 F. Supp. 2 ×5 (S.D.N.Y. 1952). 
use of his analysis in policy-making and in administration. In the broad development of public policy, the economist does not operate within the limitations of the current laws or of the judicial system. He has an opportunity to consider economic issues on a wider base, recognizing the present state of the law and the judicial system as data in his analysis. However, he is not bound by them.

It is within the economist's province to challenge the statutes and decisions as well as government policies and procedures which do not focus on litigation. He can look into government action which dulls the edge of competition as well as policies which sharpen it. He can make recommendations about the use of nonjudicial government action to inject competitive forces. For example, he can suggest the removal of a protective tariff to increase competition or the use of government purchases to induce other companies to enter into an industry.

It would be fruitless to assign fault to the lawyers or to the economists for the inadequate utilization of economic tools of analysis in the field of competition and monopoly. The task is much greater than either profession has recognized. Neither can expect the other to tackle the task alone. The process must be developed co-operatively. In order to promote such co-ordination, several activities would have to be undertaken. The legal and the economic professions would have to make organized efforts at co-operation. In this program, government agencies could make a forward contribution. Since the government agencies are the active instigators in antitrust litigation, they provide the setting for most cases. ${ }^{139}$ If they were to make wider use of economic analysis, they could exert a profound influence on their application in litigation. At the same time, their employment of economic analysis in deciding which industrial sectors need attention and in reviewing the effects of past decrees would give further impetus to the practical application of the tools of economic analysis.

Another substantial contribution could be made by the universities. Graduate students of economics can be given an appreciation of the function of economic analysis within this legal framework, and law students can be shown the uses and advantages of economic analysis. ${ }^{140}$ Various research agencies, too, can contribute to a better understanding and a testing of the methods of analysis in an effort to make them operational.

139 See Grether, supra note 5 ; KaYsen, op. cit. supra note 6, at 337-38.

${ }^{110} \mathrm{This}$, of course, is not a new suggestion. In $1908, \mathrm{H}$. W. Humble felt that perhaps lawyers should be trained as economists and economists trained as lawyers. Humble, Economics from a Legal Standpoint, 42 AM. L. REv. 379 ( I 908 ). 